\title{
Methods to Generate Chimeric Mice from Embryonic Stem Cells
}

\author{
Kun-Hsiung Lee \\ Division of Biotechnology \\ Animal Technology Institute Taiwan \\ Chunan, Miaoli, \\ Taiwan
}

\section{Introduction}

A chimera is an animal that has two or more populations of genetically distinct cells that originated in different embryos, fetuses, or individuals of the same or different species. During recent decades, embryos, the inner cell mass (ICM), teratocarcinoma stem cells, embryonal carcinoma stem cells, embryonic stem (ES) cells (ESCs), primordial germ cells, spermatogonial stem cells, extraembryonic endoderm (XEN) cells (Kunath et al., 2005), induced pluripotent stem cells (iPSCs) (Boland et al., 2009; Kang et al., 2009; Takahashi \& Yamanaka, 2006; Zhao et al., 2009), epiblast stem cells (EpiSCs) (Brons et al., 2007; Tesar et al., 2007), and other cells have been used to generate chimeric embryos that can develop into chimeras once transferred to a foster mother.

To date, three methods can be applied to produce ESC-derived chimeric embryos: (1) aggregation, (2) microinjection, and (3) coculture. This review uses mouse ES cells as an example to describe and compare existing methods for generating chimeric embryos.

\section{Methods for generating chimeric embryos}

Long before successful generation of chimeric embryos using mouse ES cells (Evans \& Kaufman, 1981; Martin, 1981), large chimeric morulae were first generated using zona pellucida (ZP)-free (denuded) pre-implantation embryos aggregated mechanically in a small drop of medium (Tarkowski, 1961). However, Tarkowski's mechanical method (via a pipette) is technically difficult and tedious for broken and removed the ZP one by one. Later, a study indicated that mouse ZP can be digested and removed easily using pronase ( 1 $\mathrm{min})$ and pipettes (Mintz, 1962). A subsequent study demonstrated that using acidic Tyrode's solution ( $\mathrm{pH}$ 2.5) to dissolve mouse $\mathrm{ZP}$ is a relatively simpler and cheaper method (Nicolson et al., 1975). A batch of intact whole embryos ( 25) submerged in the acidic Tyrode's solution for approximately 10 seconds is sufficient to partially dissolve the $\mathrm{ZP}$, and the embryos can then be transferred to a buffered medium to wash away the denuded embryos via pipettes. Aggregation has since become one of the major methods for generating chimeric embryos.

Unfortunately, once blastocysts form, generating chimeric blastocysts via the aggregation method is generally impossible. However, one may introduce cells into the cavities of blastocysts to obtain chimeric embryos. It was the first report that chimeric embryos 
produced using the five-instrument microsurgical method to introduce ICMs or cells into the blastocyst cavity (Gardner, 1968). Apparently, the five-instrument method is too complex for routine operation. Thereafter, the two-micropipette microinjection method was developed (Moustafa \& Brinster, 1972).

Since aggregation and microinjection methods are commonly used to produce chimeric embryos; techniques, equipment, and protocols have been modified and improved. For technical details of current methods, including cells, embryos, instruments, and equipment for making micropipettes and generating chimeric embryos, see previous articles (Bradley, 1987; Nagy et al., 2003; Nagy et al., 2010; Papaioannou \& Johnson, 2000; Papaioannou \& Dieterlen-Lievre, 1984; Pluck and Klasen, 2009). The website (http://www.mshri.on.ca/nagy/default.htm\#) of Professor Nagy at the Samuel Lunenfeld Research Institute, Mount Sinai Hospital, Toronto, Ontario, Canada, also provides technical protocols for generating chimeric mouse and ESC-derived mouse via aggregation between ES cells and diploid (2n) or tetraploid (4n) 2.5-day post-coitum (dpc) embryos.

Although the aggregation and microinjection methods are effective for producing chimeric embryos, due to instrumental and technical limitations, they are unsuited to mass production. Thereafter, the coculture method was developed (Wood et al., 1993a; Wood et al., 1993b).

\subsection{Comparison of conventional methods for generating chimeric mice}

Currently, the most common technique for generating chimeric embryos is direct microinjection of ES cells into the cavity of 3.5-dpc blastocysts. Microinjection is a highly stable and reproducible method that can generate good germline transmitted chimeras. However, this method has various limitations. First, an expensive micromanipulation system is required. Second, intensive training is needed to master micromanipulation skills. Third, the microinjection step is time-consuming, averaging only 20-40 blastocysts/h, limiting production to 50-100 blastocysts daily (Bradley, 1987; Hogan et al., 1994; Nagy et al., 2003). Therefore, generating chimeras usually requires pay-based services. Although using Piezo-driving (Kawase et al., 2001) to introduce ES cells into the cavity of blastocysts may have relatively better efficiency in producing chimeras, it is rarely applied as it requires a high skill level and an extra expensive device.

Well sandwich aggregation is the second most popular method for generating chimeric embryos. This method is also a highly stable, reproducible, and easy method for generating chimeras and has a germline transmission efficiency nearly equivalent to that of blastocyst microinjection (Bradley, 1987; Hogan et al., 1994; Nagy et al., 2003; Papaioannou \& Johnson, 2000). Well sandwich aggregation does not require expensive and sophisticated instruments, and is easily learned and implemented. Those familiar with using a mouth pipette can use this method routinely in a laboratory. However, two or more embryos (either $\mathrm{XX}$ or $\mathrm{XY}$ ) are required for aggregation to create a single reconstructed embryo, which is disadvantageous for inbred mice, as only 6-10 embryos can be recovered from each mouse through superovulation. Although single embryo aggregation is a viable option, its efficiency in generating chimeras varies and is inferior to methods using two or more embryos. Therefore, very few studies have used single embryo aggregation to generate chimeric embryos.

Another alternative for generating chimeric embryos is coculturing 2.5-dpc denuded single 4-cell embryos to morulae with ES cells on dish surfaces (Shimada et al., 1999; Wood et al., 1993a) or in droplets (Ueda et al., 1995). However, the efficiency of generating chimeras via this method is far inferior to that of microinjection and well sandwich aggregation. Only a few studies have used this method to generate chimeric embryos. 
Table 1 summarizes and compares conventional methods for generating chimeric embryos.

\begin{tabular}{|c|c|c|c|c|}
\hline & Microinjection & $\begin{array}{l}\text { Well sandwich } \\
\text { aggregation }^{1}\end{array}$ & $\begin{array}{c}\text { Single embryo } \\
\text { aggregation }^{1}\end{array}$ & Coculture $^{2}$ \\
\hline Equipment & Very expensive & Inexpensive & Inexpensive & Very cheap \\
\hline Skill level & Very high & Low & Low & Very low \\
\hline $\begin{array}{l}\text { Time needed to } \\
\text { learn the } \\
\text { technique }\end{array}$ & 2-3 months & 2-3 weeks & 2-3 weeks & 1-2 weeks \\
\hline $\begin{array}{l}\text { Time needed to } \\
\text { produce chimeric } \\
\text { embryos }{ }^{4}\end{array}$ & $\begin{array}{l}\text { 20-40 blastocysts/h } \\
\text { and not more than } \\
50-100 \text { blastocysts } / \mathrm{d}\end{array}$ & $\sim 30$ pairs $/ \mathrm{h}$ & $\sim 40$ embryos $/ \mathrm{h}$ & $\begin{array}{c}>100 \\
\text { embryos } / \mathrm{h}\end{array}$ \\
\hline
\end{tabular}

${ }^{1}$ Cultured overnight then reconstructed chimeric embryos are recovered for transfer or other treatments. ${ }^{2}$ Cocultured for 3-4 h, the embryo-ESC aggregates are recovered and cultured overnight to produce chimeric embryos.

${ }^{3}$ Persons must be familiar with cell and embryo culturing as well as mouth pipetting.

${ }^{4}$ Enriched ES cells and recovered intact embryos are ready for use.

Table 1. Comparison of conventional methods for generating chimeric embryos

\subsection{Vial coculture method for generating chimeric mice}

Although the microinjection method produced good and reliable results, it is hard to practice by a laboratory. Therefore, outsourcing to a core facility or commercial company is common. Unfortunately, service charges are high at approximately US\$1,000-3,000/case. Conversely, the aggregation method is easily applied and inexpensive. However, this method must be applied in a one-by-one manner and is tedious. The conventional coculture method is also easily applied and is inexpensive. Furthermore, this method facilitates routine mass production of chimeric embryos. Unfortunately, outcomes are not as reliable and good as those of the microinjection and well sandwich aggregation methods. In conventional coculture protocols, denuded embryos on a dish surface have only twodimensional ES-cell contact surfaces, resulting in only 55-64\% of denuded embryos adhering to ES cells (Ueda et al., 1995; Wood et al., 1993a). Obviously, an improved coculturing method is needed that can achieve results as good as or better than those by the microinjection and well sandwich aggregation methods. Moreover, an improved coculturing method should be easily applied, cheap, and suited to mass production.

Recently, my laboratory developed an alternative simple, very cheap, and reproducible method for mass production of chimeric embryos by coculturing 2.5-dpc denuded 8-cell embryos and compacting morulae with ES cells in 1.7-mL Eppendorf vials (micro test tube); this method has fewer technological and instrument-based limitations than conventional methods. Although depressed microwells made by a darning needle had three-dimensional possibility for denuded embryos and ES cells to contact each other, however, in the vial coculturing system, the large number of enriched ES cells surrounding the denuded embryos from every direction may improve the overall adherence. Furthermore, gravity may also contribute to enhanced ES cell adherence via this method. The resulting chimeras show significantly high levels of chimerism and high germline transmission rates (Lee et al., 2007). Table 2 lists an example schedule and protocol for the vial coculture method. Figures 1 and 2 show vial coculturing results. 


\begin{tabular}{|c|c|c|c|}
\hline Date & Time & Target & Treatment \\
\hline Friday & $\sim 16: 30$ & \multirow[b]{2}{*}{$\begin{array}{l}\text { Donor females } \\
\text { superovulated }\end{array}$} & PMSG 5-10 units/ip \\
\hline Sunday & $\sim 16: 30$ & & $\begin{array}{l}\text { hCG 5-10 units/ip; donor females are } \\
\text { mated with studs }\end{array}$ \\
\hline \multirow[b]{2}{*}{ Monday } & \multirow[b]{2}{*}{ am } & Donor females & Plug checked \\
\hline & & ES cells & $\begin{array}{l}\text { Thawed or pass in high density to } 0.1 \% \\
\text { gelatin-coated dishes }\end{array}$ \\
\hline Tuesday & $\sim 16: 30$ & $\begin{array}{l}\text { Recipients (ICR, } \\
\text { CD-1, or F1 } \\
\text { hybrid) }\end{array}$ & $\begin{array}{l}\text { Estrus females mated with vasectomized } \\
\text { males }\end{array}$ \\
\hline \multirow{11}{*}{ Wednesday } & $\mathrm{am}$ & Recipients & Plug checked \\
\hline & $\sim 08: 30$ & ES cells & Enriched via the double plating method \\
\hline & $\sim 08: 40$ & $\begin{array}{l}\text { 35-mm cell } \\
\text { culture dish }\end{array}$ & $\begin{array}{l}\text { HK }(20.85 \mathrm{mM} \text { hepes-buffered KSOM, } 285 \\
\left. \pm 10 \mathrm{mOsm} / \mathrm{kg} \mathrm{H}_{2} \mathrm{O}\right) \text { droplets under light- } \\
\text { weight mineral oil prepared; room } \\
\text { temperature (RT) }\end{array}$ \\
\hline & $\sim 09: 00$ & Donor females & $\begin{array}{l}\text { Recovery of the } 2.5 \text {-dpc embryos, which } \\
\text { are kept in HK at RT until used }\end{array}$ \\
\hline & $\sim 10: 00$ & ES cells & $\begin{array}{l}\text { The first round of enriched cells harvested } \\
\text { and re-suspended to a cell medium for the } \\
\text { second standing }\end{array}$ \\
\hline & $\sim 10: 25$ & Enriched ES cells & $\begin{array}{l}\text { Cells are harvested and stored at } 4^{\circ} \mathrm{C} \text { until } \\
\text { the concentration is adjusted for } \\
\text { coculturing }\end{array}$ \\
\hline & $\sim 10: 40$ & $\begin{array}{l}\text { 6-cell embryos to } \\
\text { compacting } \\
\text { morulae }\end{array}$ & $\begin{array}{l}\text { ZP are removed using the acidic Tyrode's } \\
\text { solution }\end{array}$ \\
\hline & $\sim 11: 00$ & 1.7-mL vials & $\begin{array}{l}\text { Approximately } 0.8 \mathrm{~mL} \text { enriched ES cells } \\
\text { are transferred to vials; after } \sim 5 \mathrm{~min} \text {, } \\
\text { denuded embryos are added for } \\
\text { coculturing; } 5 \% \mathrm{CO}_{2}, 37^{\circ} \mathrm{C} \text { incubator }\end{array}$ \\
\hline & $\sim 11: 15$ & $\begin{array}{l}60-\mathrm{mm} \\
\text { bacteriological } \\
\text { dish }\end{array}$ & $\begin{array}{l}10-\mu \mathrm{L} \text { droplets of KSOM-AA or KSOM- } \\
\text { AA containing } 1 \% \mathrm{FBS} \text { are prepared and } \\
\text { put in an incubator under } 5 \% \mathrm{CO}_{2} \text { at } 37^{\circ} \mathrm{C}\end{array}$ \\
\hline & $\sim 14: 00$ & 1.7-mL vials & $\begin{array}{l}\text { Vial coculturing ends, embryo-ESC } \\
\text { aggregates are recovered }\end{array}$ \\
\hline & $\sim 14: 30$ & $\begin{array}{l}60-\mathrm{mm} \\
\text { bacteriological } \\
\text { dish }\end{array}$ & $\begin{array}{l}\text { embryo-ESC aggregates are washed to } \\
\text { droplets of KSOM-AA or KSOM-AA } \\
\text { containing } 1 \% \mathrm{FBS} \text { for culturing } \\
\text { overnight; } 5 \% \mathrm{CO}_{2}, 37^{\circ} \mathrm{C} \text { incubator }\end{array}$ \\
\hline Thursday & am or pm & Recipients & $\begin{array}{l}\text { Chimeric embryos are transferred to } \\
\text { uterus horns of } 2.5 \text {-dpc pseudopregnant } \\
\text { recipients }\end{array}$ \\
\hline Sunday & & Recipients & Pups are born after ETed for 17 days \\
\hline
\end{tabular}

1 One person can finish the vial coculturing easily.

Table 2. Schedule and protocol for the vial coculture method for generating chimeric mice ${ }^{1}$ 


\subsubsection{Technical considerations for vial coculture method}

To ensure that cells adhered to the denuded embryos are the ES cells mainly, any enrichment method for ES cells can be used. When using the double-plating selection method, approximately $96 \%$ of harvested cells expressed bright-green fluorescence, and approximately $92 \%$ of these cells were $<12 \mu \mathrm{m}$ in diameter (Lee et al., 2007). The method is easily implemented, and is selective, effective, and reproducible in removing debris, dead cells, and feeder cells from the prepared ES single-cell suspension.

Different volumes of Eppendorf vials are available for coculturing. I recommend the 1.7-mL vial due to the size is good for handling. Approximately $0.8-\mathrm{mL}$ aliquots of enriched ES cells, either fresh or thawed; $5.0 \times 10^{5}$ cells/mL in KSOM-AA alone or KSOM-AA containing $1 \%$ fetal bovine serum (FBS) are added to sterile polypropylene 1.7-mL vials with snap caps. After left to stand for $5 \mathrm{~min}, \leqq 200$ denuded 6-cell embryos to morulae are gently and circularly blown from beneath the medium surface into the vial via a mouth pipette, and then coculture in an incubator under $5 \% \mathrm{CO}_{2}$ at $37^{\circ} \mathrm{C}$ for $3 \pm 1 \mathrm{~h}$. Denuded 2- to 4-cell embryos are unsuitable for coculturing, as blastomeres sometimes can easily separate during coculturing. Additionally, the relatively smaller diameters of blastomeres make recovery difficult. However, adherent cells are consistently observed in separated blastomeres. Conversely, segregation of blastomeres of electrofused tetraploid (4n) 3- to 4-cell embryos does not occur. After the coculturing is ended, precipitate in vials is aspirated gently and loose cells on embryonic surfaces are removed by washing using a mouth pipette. Denuded embryos adhered to ES cells are recovered. Following coculturing for $3 \mathrm{~h}$ in 1.7-mL Eppendorf vials, $>90 \%$ of denuded 6-cell embryos to morulae adherent ES cells can be recovered. Moreover, approximately $90 \%$ of recovered embryos adhered tightly to ES cells and approximately 5$10 \%$ (the percentage increases as the number of embryos in the same vial increases) of recovered aggregates had 2 or 3 embryos clustered around and adhered to ES cells. Aggregates have $>3$ embryos, if necessary, can be separated by gentle pipetting using a mouth pipette. During coculturing, approximately $10 \%$ of denuded 8-cell embryos developed into compacting morulae. Experimental data show that cell adherence could reach $100 \%$ when ES cell concentrations are increased, or when the coculturing period is extended. The embryo-ESC aggregates are washed directly in either KSOM-AA or KSOMAA containing $1 \%$ FBS droplets $(10 \mu \mathrm{L})$ under light-weight paraffin oil on bacteriological dishes. Two to four embryo-ESC aggregates are carefully allocated to different corners of the same droplet to prevent possible adhesion and are cultured overnight in an incubator at $37^{\circ} \mathrm{C}$ under $5 \% \mathrm{CO}_{2}$ until transfer to uterine horns of 2.5-dpc pseudopregnant recipients.

Mouse preimplantation embryos and ES cells require different in vitro culture requirements. Essentially, ES cells require at least 5\% FBS (Wakayama et al., 1999) to maintain survival and possible pluripotency unless cultured in knockout serum replacement (KSR) (Goldsborough et al., 1998). It has been showed that poor ES cell viability after overnight coculturing in M16 or KSOM media (Huang et al., 2008; Kondoh et al., 1999). Although, M16 supplemented with FBS, could enhance chimera generation (Kondoh et al., 1999). Unfortunately, the viable fetuses derived from the FBS (5-15\%) groups were significantly fewer than that derived from the FBS-free control group (Arny et al., 1987; Caro and Trounson, 1984; Khosla et al., 2001). Khosla et al. (2001) indicated that FBS exerts a direct adverse effect on genes responsible for postimplantation development.

To summarize, coculturing 2.5-dpc denuded 6-cell embryos to morulae with ES cells in 1.7$\mathrm{mL}$ Eppendorf vials for approximately $3 \mathrm{~h}$ is a simple and effective alternative method for mass production of chimeric embryos. Table 3 compares conventional methods and the vial coculture method for generating chimeric embryos and germline transmitted chimeric mice. 

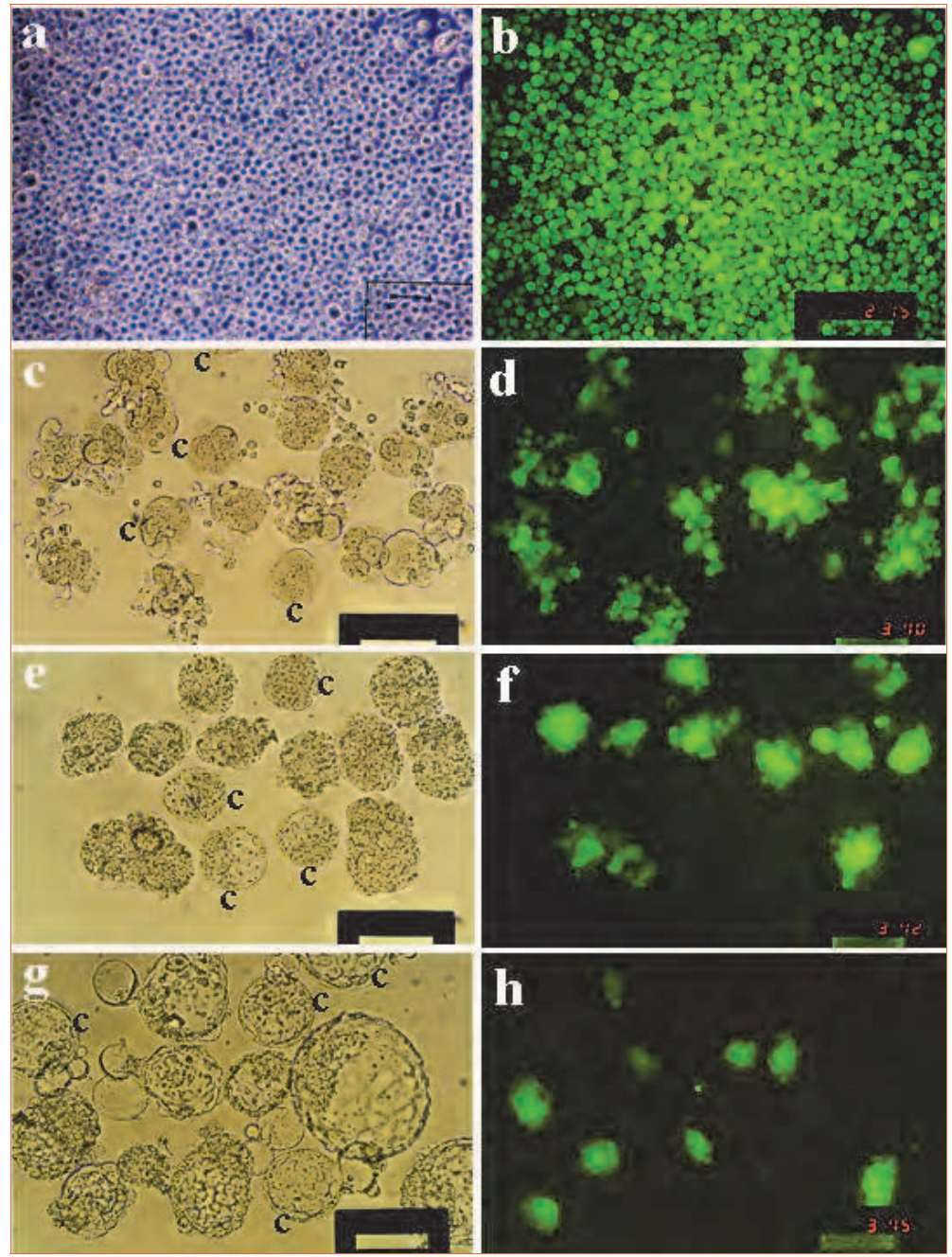

Fig. 1. Enrichment of ES cells and development of denuded embryo-ESC aggregates. a: Attaching and/or attached cells were recovered after the original single-cell suspension of the mouse ES cell, ESC 26GJ9012-8-2, cultured on a 100-mm dish in a 5\% $\mathrm{CO}_{2}$ incubator at $37^{\circ} \mathrm{C}$ for $80 \mathrm{~min}$. b: Over $94 \%$ of cells expressed the green fluorescence protein (GFP). c, d: After denuded 8-cell embryos, morulae, and ESC 26GJ9012-8-2 cells were cocultured in an 1.7-mL Eppendorf vial for $2 \mathrm{~h}$, recovered embryos had adherent green fluorescing ES cells on their surfaces. The left bright and right green fluorescent images show the same view of 14 embryos, including 28 -cell embryos, 2 compacting morulae with zona pellucida (as the control; c), 5 single-embryo-cell aggregates, 3 2-embryo-cell aggregates, and 23 -embryo-cell aggregates (some kind sandwich aggregation). e, f: After culturing aggregates from panels $\mathrm{C}$ and d overnight in droplets of KSOM-AA containing 1.0\% FBS, the aggregates had cells with surface green fluorescence mingling in the developing compacting and compacted 
chimeric morulae. g, h: After further overnight culturing, chimeric morulae from panels e and $\mathrm{f}$ developed into chimeric blastocysts displaying green fluorescence cells primarily in the ICM. Scale in panel a: bar $=50 \mu \mathrm{m}$. Scale in panels $\mathrm{b}-\mathrm{h}$ : bar $=100 \mu \mathrm{m}$. (Reproduced with permission from Lee et al., 2007. Theriogenology 67:228-237.)
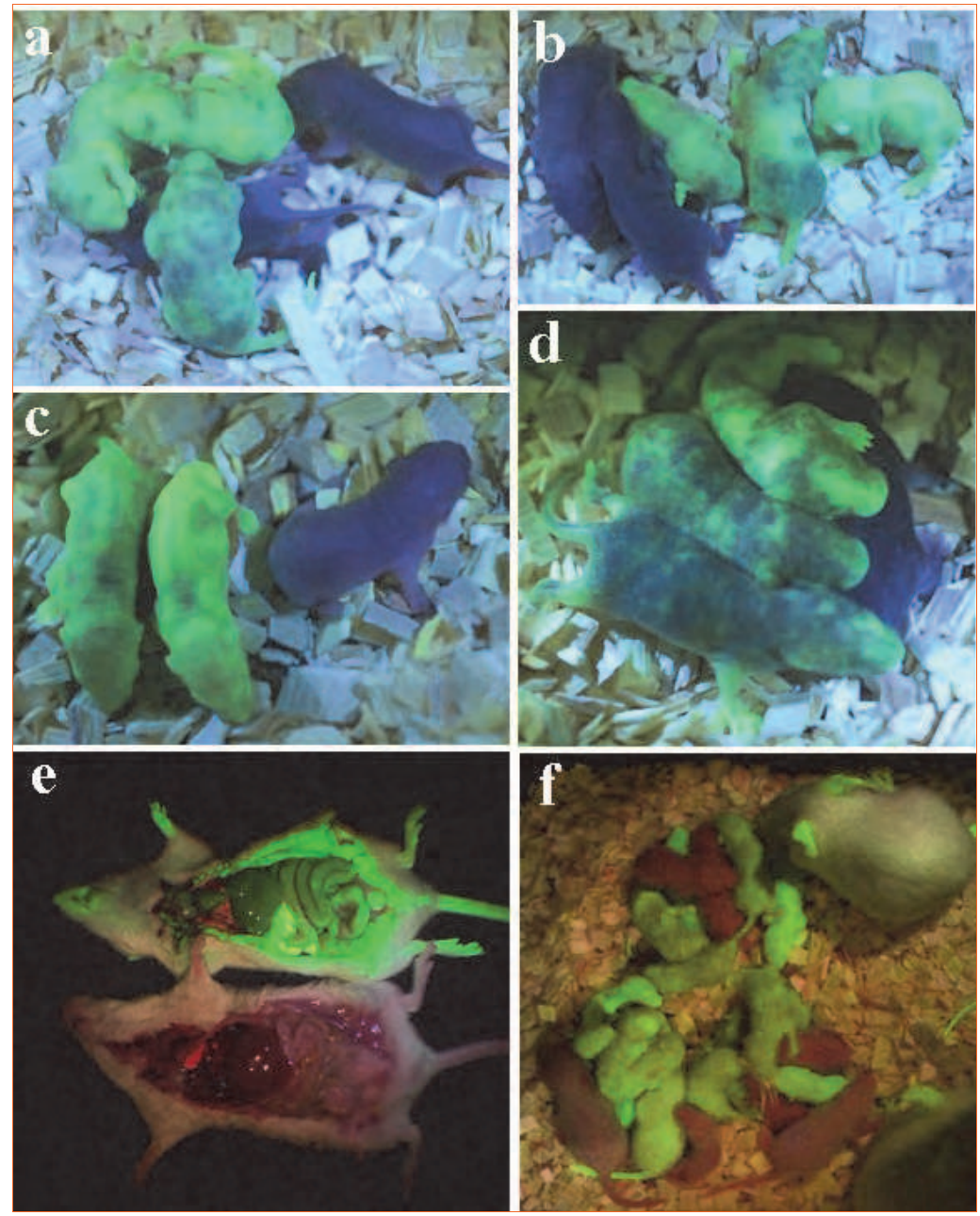

Fig. 2. Chimeras with high percentages of coat color distribution and germline transmission generated using the Eppendorf vial coculture method. In this experiment, chimeric morulae and/or blastocysts developed from aggregates of ICR $\times$ B6CBAF1 embryos and ESC 26GJ9012-8-2 cells were transferred to pseudopregnant ICR 2.5-dpc uterine horns. The pups born alive had high percentages of coat color and green fluorescence expression. a, b: Pups derived from fresh ESC 26GJ9012-8-2 cells. c, d: Pups derived from thawed ESC 26GJ9012-82 cells. e: Green fluorescence was widely expressed on internal organs of mature chimeras. The control mouse had no green fluorescence expression. f: Pups expressing green 
fluorescence, following phenotypically normal male chimeras, were naturally mated with ICR to achieve high germline transmission rates. (Reproduced with permission from Lee et al., 2007. Theriogenology 67:228-237.)

\begin{tabular}{lcccc}
\hline & Microinjection & $\begin{array}{c}\text { Well } \\
\text { sandwich } \\
\text { aggregation }\end{array}$ & $\begin{array}{c}\text { Single embryo } \\
\text { aggregation and } \\
\text { coculture }\end{array}$ & $\begin{array}{c}\text { Vial } \\
\text { coculture }\end{array}$ \\
\hline $\begin{array}{l}\text { Pups born alive after } \\
\text { chimeric embryos }\end{array}$ & $\sim 60 \%$ & $\sim 30 \%$ & $\sim 20 \%$ & $\sim 25 \%$ \\
ETed $^{2}(\mathrm{~A})$ & $\sim 50 \%$ & $\sim 55 \%$ & $\sim 45 \%$ & $\sim 60 \%$ \\
\hline $\begin{array}{l}\text { Chimeras (B) } \\
\text { Male chimeras (C) }\end{array}$ & $(\mathrm{B} / \mathrm{A})$ & $(\mathrm{B} / \mathrm{A})$ & $(\mathrm{B} / \mathrm{A})$ & $(\mathrm{B} / \mathrm{A})$ \\
\hline $\begin{array}{l}\text { Male chimeras with } \\
\text { germline } \\
\text { transmission }(\mathrm{D})\end{array}$ & $(\mathrm{C} / \mathrm{B})$ & $(\mathrm{C} / \mathrm{B})$ & $\sim 40 \%$ & $\sim 60 \%$ \\
\hline $\begin{array}{l}\text { Total efficiency of } \\
\text { germline }\end{array}$ & $\sim 30 \%$ & $\sim 40 \%$ & $(\mathrm{C} / \mathrm{B})$ & $(\mathrm{C} / \mathrm{B})$ \\
\hline $\begin{array}{l}\text { transmission } \\
(\mathrm{A} \times \mathrm{B} \times \mathrm{C} \times \mathrm{D})\end{array}$ & $(\mathrm{D} / \mathrm{C})$ & $(\mathrm{D} / \mathrm{C})$ & $(\mathrm{D} / \mathrm{C})$ & $(\mathrm{D} / \mathrm{C})$ \\
\hline
\end{tabular}

${ }^{1}$ Data are compiled from previous studies.

2Pups born alive/chimeric embryos transferred.

${ }^{3}$ Germline transmitted male chimeras/chimeric embryos transferred. The total efficiency of germline transmission is highly variables depends on ES cells used, donor embryos used, persons did, and mouse facilities managed.

Table 3. Comparative efficiency of different methods for generating germline transmitted chimeric mice ${ }^{1}$

\subsection{Generation of ESC-derived mice}

Authentic ES cells are defined by three cardinal properties: unlimited symmetrical selfrenewal in vitro; comprehensive contribution to primary chimeras; and generation of functional gametes for genome transmission (Buehr et al., 2008). However, using 4n complementation for generating ESC-derived mice is regarded as the most solid criterion for ES cell pluripotency. The criterion is also accepted for generation of iPSC-derived mice (Boland et al., 2009; Kang et al., 2009; Zhao et al., 2009).

The mouse pluripotent ES cells can be established from zygotes, blastomeres, and ICMs (Lee et al., 2011). However, the originate of ES cells limit its developmental potential to embryo proper mainly (Beddington \& Robertson, 1989). Tetraploid embryos typically stop their development during the early stage of gestation and do not develop beyond the midgestation period due to a lack of the embryo proper, but persist in extraembryonal membranes (Eakin \& Behringer, 2003; Kaufman \& Webb, 1990; Snow, 1975; Tarkowski et al., 1977). Combining $4 \mathrm{n}$ embryos and $2 \mathrm{n}$ ES cells is logical as $4 \mathrm{n}$ embryos may complement the deficient extraembryonal differentiation of ES cells while allowing full expression of their potential for fetal development (Nagy et al., 1990). Thereafter, a viable and fertile ESCderived mouse was generated (Nagy et al., 1993). 
Since ESC-derived mice were generated successfully using 4n 4-cell embryos aggregated with 2n ES cells (Nagy et al., 1990; Nagy et al., 1993), well sandwich aggregation is the main choice to do that (Eggan et al., 2002; Li et al., 2005; Ohta et al., 2008; Schoonjans et al., 2003; Ueda et al., 1995). The second popular method is microinjecting ES cells into $4 \mathrm{n}$ blastocysts (Eggan et al., 2001; Kirchain et al., 2008; Li et al., 2005; Lin et al., 2010; Schwenk et al., 2003; Wang et al., 1997; Wang \& Jaenisch, 2004).

Most tetraploid-ESC neonates derived from hybrid ES cells developed into fertile adults (Eggan et al., 2001). Conversely, most studies revealed that ESC-derived pups from inbred ES cells died shortly after delivery. However, one study demonstrated that inbred ES cells can generate ESC-derived mice (Schoonjans et al., 2003). Furthermore, the Caesarean section is required to overcome the failure of respiratory problems of ESC-newborns (Nagy et al., 1993). Apparently, this is a tedious work and is not a practical protocol for routine operation. Previous studies suggested that the recipient mothers can be subject to natural delivery instead of Caesarean section (Lee et al., 2003; Li et al., 2005). However, this is not suitable for any ES cell.

Previous studies also revealed that an ESC-derived mouse have host embryo contamination (Eggan \& Jaenisch, 2003; Li et al., 2005), poor viability, and other minor abnormalities such as altered growth rate and body weight. However, adults had normal morphological, physiological, and neurological characteristics (Schwenk et al., 2003).

Using $4 \mathrm{n}$ complementation method, $4 \mathrm{n}$ embryos require produced of $2 \mathrm{n}$ 2-cell embryos usually by electrofusion and are less viable than normal $2 \mathrm{n}$ embryos. Thus, the generation efficiency of ESC-derived mice is relatively low at approximately 1-5\%. One reason for this low efficiency may be the low cell number of $4 \mathrm{n}$ blastocysts. Using 3-5 aggregated $4 \mathrm{n}$ embryos, the efficiency in generating ESC-derived mice can be increased 2-3 times (Ohta et al., 2008). Additionally, the modified method would be applicable to any ES cell, including general ES cells used for gene targeting (Ohta et al., 2008).

Although ES cells can produce viable and fertile ESC-derived mice, this is an inefficient process; many tetraploid-ESC aggregates die before reaching term, even when early passage ES cells are used (Nagy et al., 1993). Therefore, this approach cannot be considered as a feasible approach for routinely achieving germline transmission from ES cells (Nagy et al., 1993). Reasonably, other alternatives might be developed.

\subsection{Generation of ESC-derived F0 mice}

After the blastocyst microinjected with ES cells that can adhere to and mingle in ICMs, then co-develop to an embryo proper including germ cells. The same phenomenon was also observed when 2.5-dpc embryos aggregated with ES cells. The mechanisms underlying this phenomenon have been investigated. Unfortunately, this mechanism remains unclear. However, data from studies of chimeric embryos suggest a combined contribution of multiple factors, including geometrical effects of cell size and polar or apolar positioning (Hillman et al., 1972; Johnson \& Ziomek, 1981; Saburi et al., 1997; Tarkowski \& Wroblewska, 1967). Notably, this phenomenon may also reflect the possibility that ES cells are naturally more committed to an ICM fate (Wood et al., 1993a).

Previous studies have demonstrated that ES cells adhering to the surfaces of 8-cell embryos or compacting morulae are generally localized in the ICM of blastocysts following culturing (Lee et al., 2007; Shimada et al., 1999; Wood et al., 1993a; Wood et al., 1993b). Repentigny and Kothary (2010) recently microinjected ES cells into the perivitelline space (PVS) of 
zygotes. They showed that at the 2- to 4-cell stage embryos, injected ES cells remain in the PVS and are not incorporated into embryos. The ES cells begin partial blastomere incorporation into an embryo at the 8-cell embryo. Finally, at the compacted morula, ES cells are almost completely incorporated into an embryo. At the blastocyst, ES cells form an ICM (Repentigny \& Kothary, 2010). Whether ES cells can replace ICMs completely and develop thereafter as an ESC-derived mouse is worthy of investigation.

Compared with 3.5-dpc blastocyst microinjection, an alternative method that microinjects ES cells into the tight space between ZP and blastomeres (the subzonal cavity) of 2.5-dpc 8-cell embryos has been reported (Tokunaga \& Tsunoda, 1992). Experimental results showed that the proportion of male chimeric mice capable of germline transmission increased significantly. Furthermore, $100 \%$ coat color chimeric mice with germline transmission were produced. Unfortunately, the meaning of $100 \%$ coat color chimerism was not investigated (Tokunaga \& Tsunoda, 1992). Papaioannou and Johnson $(1993,2000)$ have been mentioned that the result of microinjecting ES cells into 2.5-dpc 8-cell embryos was comparable to but not better then microinjection of 3.5-dpc blastocysts. Notably, microinjecting 2.5-dpc embryos are more difficult than microinjecting 3.5-dpc blastocysts due to the tight and small subzonal cavity and possible damage to blastomeres, explaining why only a few follow-up studies exist.

Laser-assisted microinjection of 7-9 ES cells into the subzonal cavity of $2 \mathrm{n}$ 8-cell embryos may enhance microinjection and efficiently yield F0 generation mice (100\% coat color chimerism) that are fully ESC-derived and healthy, exhibiting 100\% germline transmission and containing no more than $0.1 \%$ host embryo contamination (Poueymirou et al., 2007). They suggested that the F0 mouse is equivalent to the ESC-derived mouse. A subsequent study indicated that 8-10 ES cells Piezo (toxic mercury in a microinjection pipette used) microinjected into the subzonal cavity of $2 \mathrm{n} 4$ - or 8-cell embryos also generated F0 ES cell offspring (Huang et al., 2008).

The efficiency of generating ESC F0 mice is much better than using ESC-derived mice via ES cell assemble with 4n embryos (Eakin \& Hadjantonakis, 2006; Eggan et al., 2001; Li et al., 2005; Nagy et al., 1993; Ueda et al., 1995; Wang \& Jaenisch, 2004). However, these methods need an expensive laser or Piezo-driving equipment and additional training is required to acquire the necessary skills. The disadvantages of both methods limit their applications. Recent studies, which used conventional microinjection to introduce ES cells into 2- to 8-cell embryos, produced 100\% coat color chimeras (Kraus et al., 2010; Ramirez et al., 2009). However, the technical problems still exist.

The Eppendorf vial coculture method can generate massive amounts of chimeric embryos. The resulting chimeric mice show approximately $40 \%$ of pups born alive with almost $100 \%$ ES cells coat color distribution (Lee et al., 2007). The major disadvantage of the coculture method is variable adhesion of ES cells onto the surfaces of denuded embryos. In practice, 4cell embryos to morulae are recovered from superovulated 2.5-dpc donor mice. The denuded 8-cell embryos and morulae are good for vial coculturing. However, the 4-cell embryo is not suitable for vial coculturing, because blastomeres usually separate during coculturing.

The $2 \mathrm{n}$ ES cells microinjected into, aggregated with, or cocultured with 2.5-dpc denuded $2 \mathrm{n}$ 8-cell embryos and/or morulae can generate germline transmitted F0 mice. New methods with the higher efficiency may be worth developing to overcome the limitations and disadvantages of existing approaches. 


\subsection{The hypertonic microinjection method for generating chimeric mice}

For conventional microinjecting ES cells to 2.5-dpc 3-cell embryos to morulae, the tight subzonal cavity is a major technical hurdle. Theoretically, increasing the space of the subzonal cavity can solve this problem.

Zona pellucida is a rigid glycoprotein that resists both hypertonic and hypotonic solutions. In contrast, the volume of an embryo proper changes in proportion to osmolarity of solutions (Leibo, 1980). In other words, the space of the subzonal cavity increases when embryos are in hypertonic solutions. Notably, a high sucrose concentration is virtually nontoxic to embryos and oocytes (Kasai et al., 1983; Kasai et al., 1992; Kuleshova et al., 1999). Therefore, pre-blastocyst embryos in a microinjection medium can increase the space of the subzonal cavity proportionally to the added sucrose concentration and that may pose no threat to embryos for hours. Accordingly, my laboratory is developing a method in which ES cells are hypertonically microinjected into 2.5 -dpc embryos. Table 4 gives an example schedule and protocol for this method. The hypertonic microinjecting ES cells into 2.5-dpc embryos and fertile chimeras are shown at Fig. 3.

\begin{tabular}{|c|c|c|c|}
\hline Date & Time & Target & Treatment \\
\hline Friday & $\sim 16: 30$ & \multirow{2}{*}{$\begin{array}{l}\text { Donor females } \\
\text { superovulated }\end{array}$} & PMSG 5-10 units/ip \\
\hline Sunday & $\sim 16: 30$ & & $\begin{array}{l}\text { hCG 5-10 units/ip; Donor females are } \\
\text { mated with studs }\end{array}$ \\
\hline \multirow[b]{2}{*}{ Monday } & \multirow[b]{2}{*}{ am } & Donor females & Plug checked \\
\hline & & ES cells & $\begin{array}{l}\text { Thawed or pass in a high density to } 0.1 \% \\
\text { gelatin-coated dishes }\end{array}$ \\
\hline Tuesday & $\sim 16: 30$ & $\begin{array}{l}\text { Recipients (ICR, } \\
\text { CD-1, or F1 hybrid) }\end{array}$ & $\begin{array}{l}\text { Estrus females mated with vasectomized } \\
\text { males }\end{array}$ \\
\hline \multirow{8}{*}{ Wednesday } & am & Recipients & Plug checked \\
\hline & $\sim 08: 00$ & ES cells & Enriched via the double plating method \\
\hline & $\sim 08: 20$ & $\begin{array}{l}\text { 60-mm cell culture } \\
\text { dish }\end{array}$ & $\begin{array}{l}\text { HK, EK², and KSOM-AA droplets under } \\
\text { light-weight mineral oil prepared; RT }\end{array}$ \\
\hline & $\sim 08: 30$ & Donor females & $\begin{array}{l}\text { Recovered } 2.5 \text {-dpc embryos and stay in } \\
\text { HK at RT until used }\end{array}$ \\
\hline & $\sim 09: 30$ & $\begin{array}{l}\text { Making } \\
\text { microinjection and } \\
\text { holding pipettes }\end{array}$ & $\begin{array}{l}\text { Microinjection pipette with a beveled tip } \\
\text { and spike: outer diameter, } 18-20 \mu \mathrm{m} \text {; } \\
\text { inner diameter, } 13-15 \mu \mathrm{m} \text {. Holding } \\
\text { pipette: outer diameter, } 50-70 \mu \mathrm{m} \text {; inner } \\
\text { diameter, } 22-25 \mu \mathrm{m}\end{array}$ \\
\hline & $\sim 09: 50$ & ES cells & $\begin{array}{l}\text { The first round of enriched cells } \\
\text { harvested and re-suspended in a cell } \\
\text { medium for the second standing }\end{array}$ \\
\hline & $\sim 10: 20$ & Enriched ES cells & $\begin{array}{l}\text { Harvested cells are kept at } 4^{\circ} \mathrm{C} \text { until re- } \\
\text { suspended in high density in a hepes- } \\
\text { buffered microinjection medium }{ }^{3} \\
\text { containing } 0.2 \mathrm{M} \text { sucrose }\end{array}$ \\
\hline & $\sim 10: 40$ & $\begin{array}{l}\text { Microinjection } \\
\text { chambers }\end{array}$ & $\begin{array}{l}\text { A } \sim 80-\mu \mathrm{L} \text { droplet of } 0.2 \mathrm{M} \text { sucrose } \\
\text { microinjection medium under light- } \\
\text { weight mineral oil is prepared. }\end{array}$ \\
\hline
\end{tabular}




\begin{tabular}{|c|c|c|c|}
\hline Date & Time & Target & Treatment \\
\hline & & & $\begin{array}{l}\text { Thousands of enriched ES cells, then 3- } \\
\text { cell embryos to compacting morulae } \\
\text { added to the droplet of microinjection } \\
\text { medium in a row. }\end{array}$ \\
\hline & $\sim 10: 55$ & $\begin{array}{l}\text { 60-mm cell culture } \\
\text { dish }\end{array}$ & $\begin{array}{l}\mathrm{HK} \text {, EK, and KSOM-AA droplets under } \\
\text { light-weight mineral oil to } 5 \% \mathrm{CO}_{2}, 37^{\circ} \mathrm{C} \\
\text { incubator }\end{array}$ \\
\hline & $\sim 11: 00$ & $\begin{array}{l}\text { Microinjection } \\
\text { chamber and } \\
\text { micropipettes }\end{array}$ & Setup for microinjection \\
\hline & $\sim 11: 20$ & $\begin{array}{l}\text { Microinjection } \\
\text { chamber }\end{array}$ & $\begin{array}{l}\text { Sucking hundreds of ES cells into a } \\
\text { microinjection pipette within } 5 \sim 10 \text { min }^{5}\end{array}$ \\
\hline & $\sim 11: 30$ & $\begin{array}{l}\text { Microinjection } \\
\text { begins }\end{array}$ & $\begin{array}{l}\text { Approximately } 5-30 \text { ES cells are } \\
\text { microinjected at RT into the large } \\
\text { subzonal cavity of 3-cell embryos to } \\
\text { compacting morulae }\end{array}$ \\
\hline & $\sim 12: 30$ & $\begin{array}{l}\text { Microinjection } \\
\text { finishes }\end{array}$ & $\begin{array}{l}\text { After } 60-1502.5 \text {-dpc embryos are } \\
\text { microinjected within } 1 \mathrm{~h}^{6} \text {, injected } \\
\text { embryos are washed to and culture } \\
\text { in EK droplets for } \sim 1 \mathrm{~h} ; 5 \% \mathrm{CO}_{2}, 37^{\circ} \mathrm{C} \\
\text { incubator }\end{array}$ \\
\hline & $\sim 13: 50$ & $\begin{array}{l}\text { microinjected } \\
\text { embryos }\end{array}$ & $\begin{array}{l}\text { Wash to fresh EK or KSOM-AA droplets } \\
\text { for overnight culturing; } 5 \% \mathrm{CO}_{2}, 37^{\circ} \mathrm{C} \\
\text { incubator }\end{array}$ \\
\hline Thursday & am or $\mathrm{pm}$ & Recipients $^{7}$ & $\begin{array}{l}\text { Chimeric embryos are transferred to } \\
\text { uterus horns of } 2.5 \text {-dpc pseudopregnant } \\
\text { recipients }\end{array}$ \\
\hline Sunday & & Recipients $7^{7}$ & Pups born after ETed for 17 days \\
\hline
\end{tabular}

${ }^{1}$ Base on one person finish the hypertonic microinjection. However, two persons are more efficiently and practically.

${ }^{2}$ EK (6.5\% KSR without FBS): 37.5\% KSR ESC medium (20\% KSR) and 62.5\% KSOM-AA (285 \pm 10 $\mathrm{mOsm} / \mathrm{kg} \mathrm{H} 2 \mathrm{O}$ )

${ }^{3}$ Any hepes-buffered microinjection medium can be used. My laboratory usually uses EHK (37.5\% KSR ESC medium and $62.5 \% \mathrm{HK}$ ) as the microinjection medium no matter how ES cells are culturing either in FBS- or KSR-ESC media.

${ }^{4}$ Most enriched ES cells in $0.2 \mathrm{M}$ sucrose EHK (500 $\left.\pm 10 \mathrm{mOsm} / \mathrm{kg} \mathrm{H} \mathrm{H}_{2} \mathrm{O}\right)$ are approximately 9-11 $\mu \mathrm{m}$ in diameter. Therefore, the diameter of microinjection pipette is smaller than a conventional pipette. ${ }^{5}$ Cleaned and enriched ES cells are very important when sucking cells into a microinjection pipette. Otherwise, a single cell suspension, which has many cells with large diameters or sticky debris, will slow loading, generating a microinjection bottleneck.

${ }^{6}$ The randomly sucked embryos by a holding micropipette do not need to adjust the position for microinjecting ES cells into the subzonal cavity, which can be completed in less then 30 seconds. ${ }^{7}$ Embryos with ZP can be transferred into the oviducts of 0.5-dpc recipients (Ramirez et al., 2009). Pups will be born after being subjected to ET for 19 days.

Table 4. Schedule and protocol for the hypertonic microinjection method for generating chimeric mice ${ }^{1}$ 

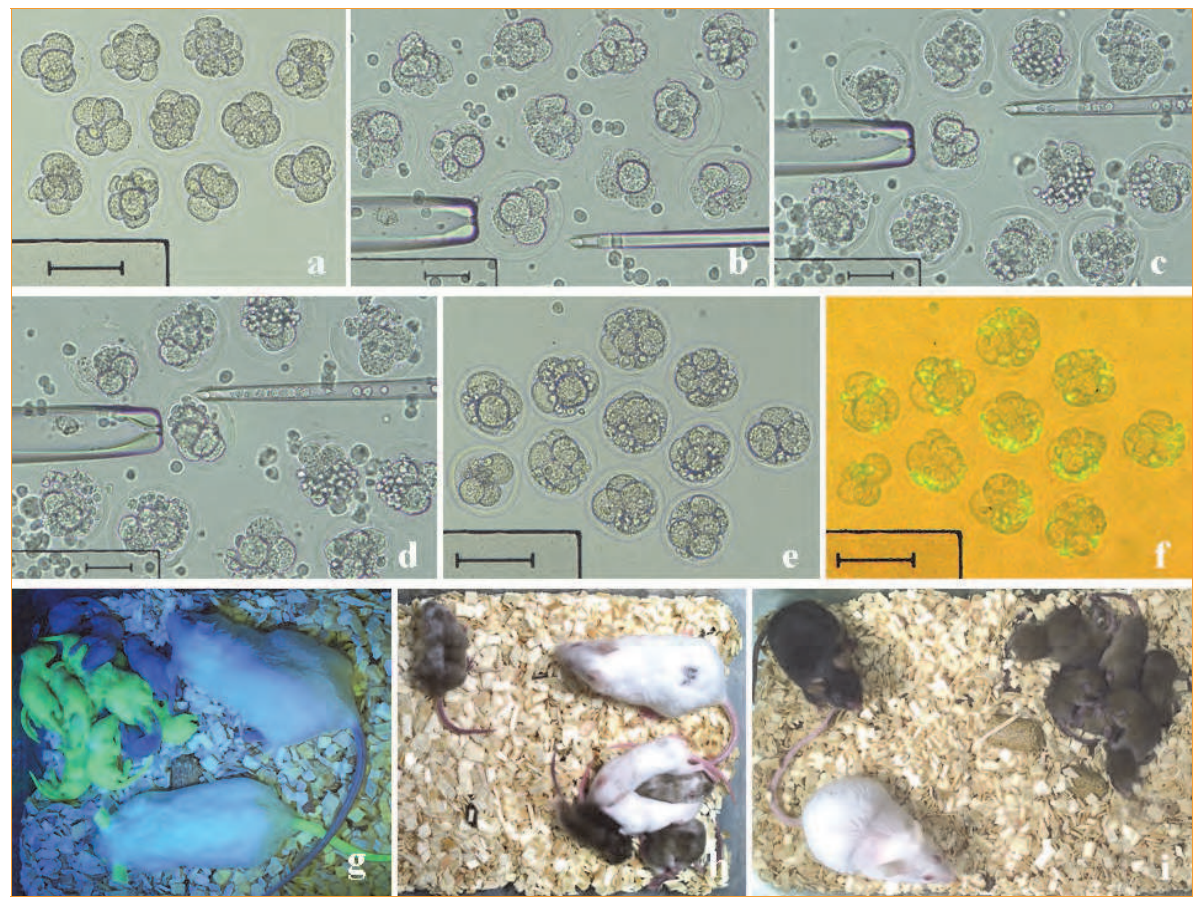

Fig. 3. The generation of germline transmitted chimeric mice via the hypertonic microinjecting ES cells into a subzonal cavity of ICR $\times$ ICR 2.5-dpc embryos. The chimeric embryos were transferred into the pseudopregnant ICR 2.5-dpc uterine horns. a: The 2.5-dpc 4- to 8-cell stage embryos in isotonic KSOM-AA ( $\left.285 \pm 10 \mathrm{mOsm} / \mathrm{kg} \mathrm{H}_{2} \mathrm{O}\right)$ have tight subzonal cavities. b: Embryos and enriched ES cells (ESC 26GJ9012-8-2, P14) in $0.2 \mathrm{M}$ sucrose EHK (37.5\% KSR ESC medium and 62.5\% hepes-KSOM) hypertonic injection medium (500 $\pm 10 \mathrm{mOsm} / \mathrm{kg} \mathrm{H}_{2} \mathrm{O}$ ) show large subzonal cavities. c, d: Injecting and injected embryos in hypertonic injection medium. e, f: After injected approximately $25 \mathrm{ES}$ cells into embryos, which were washed to isotonic EK (37.5\% KSR ESC medium and 62.5\% KSOMAA). The bright (e) and bright plus green fluorescent (f) images show the same view of 11 injected embryos. g: The green fluorescence expressing germline transmitted chimeric mouse was generated by injecting ESC 26GJ9012-8-2 cells to 4-cell embryos. h: Chimeric pups born alive after approximately 15 ESC98B33 cells (P5) were injected into 4-cell embryos and cultured overnight in EK. The ESC98B33 cell was derived from C57BL/6J 0.5-dpc denuded zygotes cultured on human foreskin fibroblast (Hs68) feeders and KSR ESC medium containing $2 \mathrm{i}(0.5 \mu \mathrm{M}$ PD0325901 and $3 \mu \mathrm{M}$ CHIR99021) and $10 \mu \mathrm{M}$ ACTH fragments 1-24. i: A chimeric mouse with $100 \%$ coat color distribution was generated after approximately 20 ESC98B27 cells (P8) were injected into compacting morulae and cultured overnight in KSOM-AA. The ESC98B27 cell was derived from an isolated single blastomere of a C57BL/6J 1.5-dpc 2-cell embryo cultured on Hs68 feeders and KSR ESC medium containing 2i. Scale in panels a, e, f: bar $=100 \mu \mathrm{m}$. Scale in panels b-d: bar $=50 \mu \mathrm{m}$.

Preliminary data demonstrate that ES cells microinjected into the subzonal cavity of 2.5-dpc embryos in a microinjection medium containing $0.2 \mathrm{M}$ sucrose $\left(\sim 500 \mathrm{mOsm} / \mathrm{kg} \mathrm{H}_{2} \mathrm{O}\right)$ can 
generate chimeric embryos with high percentages of chimerism (including $100 \%$ coat color and/or GFP expression) and viable, healthy, germline transmitted mice (Fig. 3). These preliminary results also indicate that hypertonic microinjection is at least comparable to conventional, laser, and Piezo microinjection methods for generating germline-transmitted chimeras.

Technically, the differences between conventional microinjection and hypertonic microinjection are that later method uses the $0.2 \mathrm{M}$ sucrose microinjection medium, a microinjection pipette with a smaller diameter, and very fast microinjection. The developing hypertonic microinjection method may be an useful alternative for generating chimeric or F0 mice.

\subsection{Optimal method of generating chimeras depends on embryo stage}

Depending on embryo stage, germline transmitted chimeric mouse or F0 mouse are generated by microinjection, well sandwich aggregation, or coculture methods. Typically, embryos recovered from 0.5-dpc (zygotes) and 1.5-dpc (2-cell embryos) mice for use in generating chimeras are usually no better than 2.5-dpc and 3.5-dpc (Repentigny \& Kothary, 2010). In practice, therefore, 3.5-dpc and 2.5-dpc embryos are more commonly used. For blastocysts, conventional microinjection is the only choice. For pre-blastocyst embryos, almost all methods are possible. However, the optimal method may differ. The comparative efficiency of methods for generating germline transmitted chimeric mouse or F0 mouse is summarized at the Table 5, which also might be adopted for generation of ES cell-derived mouse via $4 \mathrm{n}$ embryos.

\begin{tabular}{|c|c|c|c|c|c|}
\hline \multirow[b]{2}{*}{ Embryo stage } & \multicolumn{3}{|c|}{$2.5-\mathrm{dpc}$} & \multicolumn{2}{|c|}{ 3.5-dpc } \\
\hline & $\begin{array}{c}\text { 3-cell to 5-cell } \\
\text { embryo }\end{array}$ & $\begin{array}{c}\text { 6-cell to 8-cell } \\
\text { embryo }\end{array}$ & $\begin{array}{c}\text { Compacting } \\
\text { morula }^{3}\end{array}$ & $\begin{array}{c}\text { Compacted } \\
\text { morula }^{3}\end{array}$ & Blastocyst \\
\hline $\begin{array}{l}\text { Conventional } \\
\text { microinjection }\end{array}$ & + & + & + & + & +++ \\
\hline $\begin{array}{l}\text { Hypertonic } \\
\text { microinjection }\end{array}$ & ++ & +++ & +++ & + & +- \\
\hline $\begin{array}{l}\text { Laser-assisted } \\
\text { microinjection }\end{array}$ & + & + & + & + & +- \\
\hline $\begin{array}{l}\text { Piezo-driving } \\
\text { microinjection }\end{array}$ & + & + & + & + & +- \\
\hline $\begin{array}{l}\text { Well sandwich } \\
\text { aggregation }\end{array}$ & ++ & +++ & +++ & - & - \\
\hline $\begin{array}{l}\text { Single embryo } \\
\text { aggregation }\end{array}$ & +- & + & + & - & - \\
\hline $\begin{array}{l}\text { Conventional } \\
\text { coculture }\end{array}$ & +- & + & + & - & - \\
\hline Vial coculture & + & +++ & +++ & - & - \\
\hline
\end{tabular}

${ }^{1}$ Methods are compared in terms of efficiency in generating germline transmitted chimeras, required equipment, required skills, and operational time.

2+++: best; ++: 2 nd choice; +: 3 rd choice; +-: not suggested -: not good at all.

${ }^{3}$ Compacting and compacted morulae can be cultured in Ca++-, $\mathrm{Mg}++-$ free PBS for 30-60 min to reveal the blastomeres. In some cases, approximately $10 \mathrm{ES}$ cells can be directly microinjected into an embryo proper.

Table 5. Comparative efficiency of methods for generating germline-transmitted chimeric mouse or F0 mouse ${ }^{1,2}$ 


\section{Conclusion}

Currently, the most common techniques for generating chimeric mice or ESC-derived mice are microinjection or well sandwich aggregation. Single denuded embryo aggregation or coculturing with ES cells are less common alternatives because the efficiency in generating chimeras is inferior to that of microinjection and well sandwich aggregation. Thus, both methods are rarely employed. However, due to systemic limitations and the disadvantages of conventional microinjection, aggregation, and coculturing, new methods are needed.

Recently, my laboratory developed an alternative simple, inexpensive, and reproducible method for mass production of chimeric embryos by coculturing 2.5-dpc denuded 8-cell embryos and/or compacting morulae with ES cells in 1.7-mL Eppendorf vials (micro test tube). This vial coculture method has significantly fewer technological and instrumental problems than existing methods. The resulting chimeras have significant levels of chimerism (including 100\% coat color chimerism) and high germline transmission rates.

Previous studies showed that microinjecting ES cells into 2.5-dpc 8-cell embryos could produce $100 \%$ coat color chimerism. However, due to the tight space between ZP and blastomeres, one must be very careful to avoid damaging blastomeres while microinjecting. Thus, the method is rarely adopted. Using a laser pulse or Piezo-driving equipment to assist introducing ES cells into the subzonal cavity of 8-cell embryos could have superior efficiency in generating ESC-derived F0 chimeras (100\% coat color chimerism), which are equivalent to ESC-derived mice. However, only few studies have adopted either method due to the skill and/or extra expensive instruments needed.

Recently, my laboratory revealed that ES cells microinjected into the subzonal cavity of 2.5dpc embryos in a microinjection medium supplemented with $0.2 \mathrm{M}$ sucrose could efficiently generate chimeric embryos with high percentages of chimerism and viable, healthy, germline transmitted F0 ES-cell mice.

Both vial coculture and hypertonic microinjection methods are useful alternatives for producing germline chimeric or F0 mice effectively, efficiently, and reliably.

\section{Acknowledgments}

Parts of the contents have been published at the journal of Theriogenology (Lee et al., 2007; 67:228-237). Special thanks to co-authors. Also, I would like to thank the National Science Council of the Republic of China, Taiwan, for financially supporting my research under Contract Nos. NSC99-2324-B-059-001, NSC97-2317-B-059-004, and NSC95-2317-B-059-001. Drs. C.F. Tu, C.k. Juang, and S.F. Guo as well as Ms. H.R. Chang and T.L. Hsu at Animal Technology Institute Taiwan (ATIT) are commended for their critical comments, technical assistance, and routine maintenance in the laboratory and mouse facility.

\section{References}

Arny, M., L. Nachtigall, \& J. Quagliarello. (1987). The effect of preimplantation culture conditions on murine embryo implantation and fetal development. Fertility and Sterility 48:861-865.

Beddington, R. S. \& E. J. Robertson. (1989). An assessment of the developmental potential of embryonic stem cells in the midgestation mouse embryo. Development 105:733-737. 
Boland, M. J., J. L. Hazen, K. L. Nazor, A. R. Rodriguez, W. Gifford, G. Martin, S. Kupriyanov, \& K. K. Baldwin. (2009). Adult mice generated from induced pluripotent stem cells. Nature 461:91-94.

Bradley, A. (1987). Production and analysis of chimeric mice. In: Teratocarcinomas and Embryonic Stem Cells, a Practical Approach. E. J. Robertson, (Ed.), pp. 113-151. IRL Press, ISBN 1-85221-004-4, Oxford, UK.

Brons, I. G., L. E. Smithers, M. W. B. Trotter, P. Rugg-Gunn, B. Sun, S. Chuva de Sousa Lopes, S. K. Howlett, A. Clarkson, L. hrlund-Richter, R. A. Pedersen, \& L. Vallier. (2007). Derivation of pluripotent epiblast stem cells from mammalian embryos. Nature 448:191-195.

Buehr, M., S. Meek, K. Blair, J. Yang, J. Ure, J. Silva, R. McLay, J. Hall, Q. L. Ying, \& A. Smith. (2008). Capture of authentic embryonic stem cells from rat blastocysts. Cell 135:1287-1298.

Caro, C. M. \& A. Trounson. (1984). The effect of protein on preimplantation mouse embryo development in vitro. Journal of In Vitro Fertilization and Embryo Transfer 1:183-187.

Eakin, G. S. \& R. R. Behringer. (2003). Tetraploid development in the mouse. Developmental Dynamics 228:751-766.

Eakin, G. S. \& A. K. Hadjantonakis. (2006). Production of chimeras by aggregation of embryonic stem cells with diploid or tetraploid mouse embryos. Nature Protocols 1:1145-1153.

Eggan, K. \& R. Jaenisch. (2003). Differentiation of F1 embryonic stem cells into viable male and female mice by tetraploid embryo complementation. Methods in Enzymology 365:25-39.

Eggan, K., H. Akutsu, J. Loring, L. Jackson-Grusby, M. Klemm, W. M. Rideout, R. Yanagimachi, \& R. Jaenisch. (2001). Hybrid vigor, fetal overgrowth, and viability of mice derived by nuclear cloning and tetraploid embryo complementation. Proceedings of the National Academy of Sciences USA 98:6209-6214.

Eggan, K., A. Rode, I. Jentsch, C. Samuel, T. Hennek, H. Tintrup, B. Zevnik, J. Erwin, J. Loring, L. Jackson-Grusby, M. R. Speicher, R. Kuehn, \& R. Jaenisch. (2002). Male and female mice derived from the same embryonic stem cell clone by tetraploid embryo complementation. Nature Biotechnology 20:455-459.

Evans, M. J. \& M. H. Kaufman. (1981). Establishment in culture of pluripotential cells from mouse embryos. Nature 292:154-156.

Gardner, R. L. (1968). Mouse chimeras obtained by the injection of cells into the blastocyst. Nature 220:596-597.

Goldsborough, M. D., M. L. Tilkins, P. J. Price, J. Lobo-Alfonso, J. R. Morrison, M. E. Stevens, J. Meneses, R. Pederson, R. Koller, B. Koller, \& A. Latour. (1998). Serum-free culture of murine embryonic stem (ES) cells. Focus (Gibco) 20:8-12.

Hillman, N., M. I. Sherman, \& C. Graham. (1972). The effect of spatial arrangement on cell determination during mouse development. Journal of Embryology and Experimental Morphology 28:263-278.

Hogan, B., F. Costantini, R. Beddington, \& E. Lacy. (1994). In vitro manipulation of preimplantation embryos. In: Manipulating the Mouse Embryo, a Laboratory Manual. B. Hogan, F. Costantini, R. Beddington, \& E. Lacy, (Eds.), pp. 189-216. Cold Spring Harbor Lab. Press, ISBN 0-87969-384-3, Plainview, USA. 
Huang, J., K. Deng, H. Wu, Z. Liu, Z. Chen, S. Cao, L. Zhou, X. Ye, D. L. Keefe, \& L. Liu. (2008). Efficient production of mice from embryonic stem cells injected into four- or eight-cell embryos by piezo micromanipulation. Stem Cells 26:1883-1890.

Johnson, M. H. \& C. A. Ziomek. (1981). Induction of polarity in mouse 8-cell blastomeres: Specificity, geometry, and stability. Journal of Cell Biology 91:303-308.

Kang, L., J. Wang, Y. Zhang, Z. Kou, \& S. Gao. (2009). iPS cells can support full-term development of tetraploid blastocyst-complemented embryos. Cell Stem Cell 5:135138.

Kasai, M., M. Nishimori, S. E. Zhu, T. Sakurai, \& T. Machida. (1992). Survival of mouse morulae vitrified in an ethylene glycol-based solution after exposure to the solution at various temperatures. Biology of Reproduction 47:1134-1139.

Kasai, M., K. Niwa, \& A. Iritani. (1983). Protective effect of sucrose on the survival of mouse and rat embryos stored at $0^{\circ} \mathrm{C}$. Journal of Reproduction and Fertility 68:377-380.

Kaufman, M. H. \& S. Webb. (1990). Postimplantation development of tetraploid mouse embryos produced by electrofusion. Development 110:1121-1132.

Kawase, Y., T. Iwata, M. Watanabe, N. Kamada, O. Ueda, \& H. Suzuki. (2001). Application of the piezo-micromanipulator for injection of embryonic stem cells into mouse blastocysts. Contemporary Topics in Laboratory Animal Science 40:31-34.

Khosla, S., W. Dean, D. Brown, W. Reik, \& R. Feil. (2001). Culture of preimplantation mouse embryos affects fetal development and the expression of imprinted genes. Biology of Reproduction 64:918-926.

Kirchain, S. M., A. M. Hayward, J. M. Mkandawire, P. Qi, \& A. A. Burds. (2008). Comparison of tetraploid blastocyst microinjection of outbred Crl:CD1(ICR), hybrid B6D2F1/Tac, and inbred C57BL/6NTac embryos for generation of mice derived from embryonic stem cells. Comparative Medicine 58:145-150.

Kondoh, G., Y. Yamamoto, K. Yoshida, Y. Suzuki, S. Osuka, Y. Nakano, T. Morita, \& J. Takeda. (1999). Easy assessment of ES cell clone potency for chimeric development and germ-line competency by an optimized aggregation method. Journal of Biochemical and Biophysical Methods 39:137-142.

Kraus, P., G. Leong, V. Tan, X. Xing, J. W. Goh, S. P. Yap, \& T. Lufkin. (2010). A more cost effective and rapid high percentage germ-line transmitting chimeric mouse generation procedure via microinjection of 2-cell, 4-cell, and 8-cell embryos with ES and iPS cells. Genesis 48:394-399.

Kuleshova, L. L., D. R. MacFarlane, A. O. Trounson, \& J. M. Shaw. (1999). Sugars exert a major influence on the vitrification properties of ethylene glycol-based solutions and have low toxicity to embryos and oocytes. Cryobiology 38:119-130.

Kunath, T., D. Arnaud, G. D. Uy, I. Okamoto, C. Chureau, Y. Yamanaka, E. Heard, R. L. Gardner, P. Avner, \& J. Rossant. (2005). Imprinted X-inactivation in extraembryonic endoderm cell lines from mouse blastocysts. Development 132:1649-1661.

Lee, K. H., H. R. Chang, H. W. Wang, C. J. Lin, S. C. Wu, \& C. F. Tu. (2003). Natural farrowed fertile mice derived from green fluorescent embryonic stem cells. Journal of the Chinese Society of Animal Science 32(4):91 (Abstr.)

Lee, K. H., C. k. Chuang, H. W. Wang, L. Stone, C. H. Chen, \& C. F. Tu. (2007). An alternative simple method for mass production of chimeric embryos by coculturing denuded embryos and embryonic stem cells in Eppendorf vials. Theriogenology 67:228-237. 
Lee, K. H., C. k. Chuang, S. F. Guo, \& C. F. Tu. (2011). Simple and efficient derivation of mouse embryonic stem cell lines using differentiation inhibitors or proliferation stimulators. Stem Cells and Development (In Press; DOI: 10.1089/scd.2011.0021)

Leibo, S. P. (1980). Water permeability and its activation energy of fertilized and unfertilized mouse ova. Journal of Membrane Biology 53:179-188.

Li, X., Y. Yu, W. Wei, J. Yong, J. Yang, J. You, X. Xiong, T. Qing, \& H. Deng. (2005). Simple and efficient production of mice derived from embryonic stem cells aggregated with tetraploid embryos. Molecular Reproduction and Development 71:154-158.

Lin, C. J., T. Amano, J. Zhang, Y. E. Chen, \& X. C. Tian. (2010). Acceptance of embryonic stem cells by a wide developmental range of mouse tetraploid embryos. Biology of Reproduction 83:177-184.

Martin, G. R. (1981). Isolation of a pluripotent cell line from early mouse embryos cultured in medium conditioned by teratocarcinoma stem cells. Proceedings of the National Academy of Sciences USA 78:7634-7638.

Mintz, B. (1962). Formation of genotypically mosaic mouse embryos. American Zoologist 2:432 (Abstr.)

Moustafa, L. A. \& R. L. Brinster. (1972). Induced chimaerism by transplanting embryonic cells into mouse blastocysts. Journal of Experimental Zoology 181:193-201.

Nagy, A., M. Gertsenstein, K. Vintersten, \& R. Behringer. (2003). Production of Chimeras. In: Manipulating the Mouse Embryo, a Laboratory Manual. A. Nagy, M. Gertsenstein, K. Vintersten, \& R. Behringer, (Eds.), pp. 453-506. Cold Spring Harbor Lab. Press, ISBN 0-87969-574-9, New York, USA.

Nagy, A., E. Gocza, E. M. Diaz, V. R. Prideaux, E. Ivanyi, M. Markkula, \& J. Rossant. (1990). Embryonic stem cells alone are able to support fetal development in the mouse. Development 110:815-821.

Nagy, A., J. Rossant, R. Nagy, W. bramow-Newerly, \& J. C. Roder. (1993). Derivation of completely cell culture-derived mice from early-passage embryonic stem cells. Proceedings of the National Academy of Sciences USA 90:8424-8428.

Nagy, A., K. Nagy, \& M. Gertsenstein. (2010). Production of mouse chimeras by aggregating pluripotent stem cells with embryos. In: Methods in Enzymology, Vol. 476: Guide to Techniques in Mouse Development, Part A: Mice, Embryos, and Cells, 2nd Ed. P. Wassarman (Ed.). pp. 123-149. Academic Press, ISBN 9780123747754, USA.

Nicolson, G. L., R. Yanagimachi, \& H. Yanagimachi. (1975). Ultrastructural localization of lectin-binding sites on the zonae pellucidae and plasma membranes of mammalian eggs. Journal of Cell Biology 66:263-274.

Ohta, H., Y. Sakaide, K. Yamagata, \& T. Wakayama. (2008). Increasing the cell number of host tetraploid embryos can improve the production of mice derived from embryonic stem cells. Biology of Reproduction 79:486-492.

Papaioannou, V. \& R. Johnson. (1993). Production of chimeras and genetically defined offspring from targeted ES cells. In: Gene Targeting, a Practical Approach. A. L. Joyner, (ed.), pp. 107-146. IRL Press, Oxford Univ. Press, ISBN 0-19-963406-8, Oxford, UK.

Papaioannou, V. \& R. Johnson. (2000). Production of chimeras by blastocyst and morula injection of targeted ES cells. In: Gene Targeting, a Practical Approach. 2nd Ed. A. L. Joyner, (ed.), pp. 133-175. Oxford Univ. Press, ISBN 0-19-963792-X, Oxford, UK. 
Papaioannou, V. E. \& F. Dieterlen-Lievre. (1984). Making Chimeras. In: Chimeras in Developmental Biology. N. Douarin \& A. McLaren, (eds.), pp. 3-37. Academic Press, ISBN 0-12-440580-0, USA.

Pluck, A. \& C. Klasen. (2009). Generation of chimeras by morula aggregation. Methods in Molecular Biology 561:219-229.

Poueymirou, W. T., W. Auerbach, D. Frendewey, J. F. Hickey, J. M. Escaravage, L. Esau, A. T. Dore, S. Stevens, N. C. Adams, M. G. Dominguez, N. W. Gale, G. D. Yancopoulos, T. M. DeChiara, \& D. M. Valenzuela. (2007). F0 generation mice fully derived from gene-targeted embryonic stem cells allowing immediate phenotypic analyses. Nature Biotechnology 25:91-99.

Ramirez, M. A., R. Fernandez-Gonzalez, M. Perez-Crespo, E. Pericuesta, \& A. GutierrezAdan. (2009). Effect of stem cell activation, culture media of manipulated embryos, and site of embryo transfer in the production of F0 embryonic stem cell mice. Biology of Reproduction 80:1216-1222.

Repentigny, Y. \& R. Kothary. (2010). Production of mouse chimeras by injection of embryonic stem cells into the perivitelline space of one-cell stage embryos. Transgenic Research 19:1137-1144.

Saburi, S., S. Azuma, E. Sato, Y. Toyoda, \& C. Tachi. (1997). Developmental fate of single embryonic stem cells microinjected into 8-cell-stage mouse embryos. Differentiation 62:1-11.

Schoonjans, L., V. Kreemers, S. Danloy, R. W. Moreadith, Y. Laroche, \& D. Collen. (2003). Improved generation of germline-competent embryonic stem cell lines from inbred mouse strains. Stem Cells 21:90-97.

Schwenk, F., B. Zevnik, J. Bruning, M. Rohl, A. Willuweit, A. Rode, T. Hennek, G. Kauselmann, R. Jaenisch, \& R. Kuhn. (2003). Hybrid embryonic stem cell-derived tetraploid mice show apparently normal morphological, physiological, and neurological characteristics. Molecular Cell Biology 23:3982-3989.

Shimada, H., T. Kaname, M. Suzuki, Y. Hitoshi, K. Araki, T. Imaizumi, \& K. Yamamura. (1999). Comparison of ES cell fate in sandwiched aggregates and co-cultured aggregates during blastocyst formation by monitored GFP expression. Molecular Reproduction and Development 52:376-382.

Snow, M. H. (1975). Embryonic development of tetraploid mice during the second half of gestation. Journal of Embryology and Experimental Morphology 34:707-721.

Takahashi, K. \& S. Yamanaka. (2006). Induction of pluripotent stem cells from mouse embryonic and adult fibroblast cultures by defined factors. Cell 126:663-676.

Tarkowski, A. K. (1961). Mouse chimaeras developed from fused eggs. Nature 190:857-860.

Tarkowski, A. K., A. Witkowska, \& J. Opas. (1977). Development of cytochalasin B-induced tetraploid and diploid/tetraploid mosaic mouse embryos. Journal of Embryology and Experimental Morphology 41:47-64.

Tarkowski, A. K. \& J. Wroblewska. (1967). Development of blastomeres of mouse eggs isolated at the 4- and 8-cell stage. Journal of Embryology and Experimental Morphology 18:155-180.

Tesar, P. J., J. G. Chenoweth, F. A. Brook, T. J. Davies, E. P. Evans, D. L. Mack, R. L. Gardner, \& R. D. G. McKay. (2007). New cell lines from mouse epiblast share defining features with human embryonic stem cells. Nature 448:196-199. 
Tokunaga, T. \& Y. Tsunoda. (1992). Efficacious production of viable germ-line chimeras between embryonic stem (ES) cells and 8-cell stage embryos. Development, Growth and Differentiation 34:561-566.

Ueda, O., N. Kamada, K. Jishage, S. Uchida, \& H. H.Suzuki. (1995). Factors affecting the efficiency of chimera production by coculture of zona-free embryos with frozenthawed embryonic stem cells in mice. Journal of Reproduction and Development 41:181-186.

Wakayama, T., I. Rodriguez, A. C. F. Perry, R. Yanagimachi, \& P. Mombaerts. (1999). Mice cloned from embryonic stem cells. Proceedings of the National Academy of Sciences USA 96:14984-14989.

Wang, Z. Q., F. Kiefer, P. Urbanek, \& E. F. Wagner. (1997). Generation of completely embryonic stem cell-derived mutant mice using tetraploid blastocyst injection. Mechanisms of Development 62:137-145.

Wang, Z. \& R. Jaenisch. (2004). At most three ES cells contribute to the somatic lineages of chimeric mice and of mice produced by ES-tetraploid complementation. Developmental Biology 275:192-201.

Wood, S. A., W. S. Pascoe, C. Schmidt, R. Kemler, M. J. Evans, \& N. D. Allen. (1993a). Simple and efficient production of embryonic stem cell-embryo chimeras by coculture. Proceedings of the National Academy of Sciences USA 90:4582-4585.

Wood, S. A., N. D. Allen, J. Rossant, A. Auerbach, \& A. Nagy. (1993b). Non-injection methods for the production of embryonic stem cell-embryo chimaeras. Nature 365:87-89.

Zhao, X. Y., W. Li, Z. Lv, L. Liu, M. Tong, T. Hai, J. Hao, C. 1. Guo, Q. W. Ma, L. Wang, F. Zeng, \& Q. Zhou. (2009). iPS cells produce viable mice through tetraploid complementation. Nature 461:86-90. 


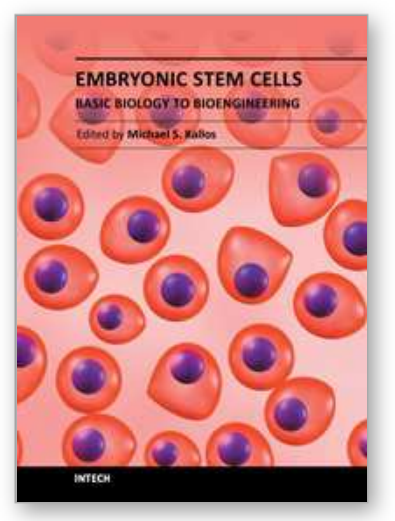

\author{
Embryonic Stem Cells - Basic Biology to Bioengineering \\ Edited by Prof. Michael Kallos
}

ISBN 978-953-307-278-4

Hard cover, 478 pages

Publisher InTech

Published online 15, September, 2011

Published in print edition September, 2011

Embryonic stem cells are one of the key building blocks of the emerging multidisciplinary field of regenerative medicine, and discoveries and new technology related to embryonic stem cells are being made at an ever increasing rate. This book provides a snapshot of some of the research occurring across a wide range of areas related to embryonic stem cells, including new methods, tools and technologies; new understandings about the molecular biology and pluripotency of these cells; as well as new uses for and sources of embryonic stem cells. The book will serve as a valuable resource for engineers, scientists, and clinicians as well as students in a wide range of disciplines.

\title{
How to reference
}

In order to correctly reference this scholarly work, feel free to copy and paste the following:

Kun-Hsiung Lee (2011). Methods to Generate Chimeric Mice from Embryonic Stem Cells, Embryonic Stem Cells - Basic Biology to Bioengineering, Prof. Michael Kallos (Ed.), ISBN: 978-953-307-278-4, InTech, Available from: http://www.intechopen.com/books/embryonic-stem-cells-basic-biology-to-bioengineering/methods-togenerate-chimeric-mice-from-embryonic-stem-cells

\section{INTECH}

open science | open minds

\section{InTech Europe}

University Campus STeP Ri Slavka Krautzeka 83/A 51000 Rijeka, Croatia Phone: +385 (51) 770447

Fax: +385 (51) 686166 www.intechopen.com

\section{InTech China}

Unit 405, Office Block, Hotel Equatorial Shanghai No.65, Yan An Road (West), Shanghai, 200040, China 中国上海市延安西路65号上海国际贵都大饭店办公楼405单元 Phone: +86-21-62489820

Fax: +86-21-62489821 
(C) 2011 The Author(s). Licensee IntechOpen. This chapter is distributed under the terms of the Creative Commons Attribution-NonCommercialShareAlike-3.0 License, which permits use, distribution and reproduction for non-commercial purposes, provided the original is properly cited and derivative works building on this content are distributed under the same license. 